\title{
Differences in the expression of selected genes associated with cell stress response in a PTSD patient and in healthy individuals - a case study
}

\author{
Anna Rasmus ${ }^{1}$, Paweł Półrola ${ }^{2}$, Jolanta Góral-Półrola ${ }^{3}$, Małgorzata Żychowska ${ }^{4}$, Andrzej Mirski ${ }^{5}$, \\ Henryk Knapik \\ 1 Institute of Psychology, Kazimierz Wielki University, Bydgoszcz, Poland \\ ${ }^{2}$ Faculty of Medicine and Health Sciences, Jan Kochanowski University in Kielce, Kielce, Poland \\ ${ }^{3}$ The Old Polish University, Kielce, Poland \\ ${ }^{4}$ Department of Life Sciences, Gdańsk University of Physical Education and Sport, Gdańsk, Poland \\ ${ }^{5}$ Chair of Neuropsychology, The Andrzej Frycz-Modrzewski Cracow University, Kraków, Poland \\ ${ }^{6}$ The Department of Physiotherapy, Academy of Physical Education, Katowice, Poland \\ Rasmus A, Półrola P, Góral-Półrola J, Żychowska M, Mirski A, Knapik H. Differences in the expression of selected genes associated \\ with cell stress response in a PTSD patient and in healthy individuals - a case study. Ann Agric Environ Med. $2017 ; 24(2)$ : 332-337. \\ https://doi.org/10.26444/aaem/74711
}

\section{Abstract}

Objective. The aim of the study was determination of the level in expression genes associated with cell stress response in a patient with PTSD.

Case study. A 57-year-old PTSD patient, A.P., was the subject of the study. Blood samples were taken from the ulnar vein to assess the relative expression of the tested genes in leukocytes via a quantitative reverse transcription polymerase chain reaction (qRT-PCR).

Results. A considerably decreased level in the expression HSF-1, NF-kB, Hif-1 and IL6 m-RNA was observed in the patient when compared to the control group. A low expression in HSPA1A, HSPB1, IL10 and CRP m-RNA compared with the control group was also noted.

Conclusion. It is possible that the lower level of transcriptional factors: HSF-1, NF-kB and Hif-1 as well as IL6 m-RNA may be associated with the effect of the PTSD patient's treatment.

\section{Key words}

cell stress, PTSD patient, expression of selected genes, healthy individuals

\section{INTRODUCTION}

The occurrence of illness within an organism is accompanied by changes in gene expression. Too high or too low an expression level among particular genes impacts on disturbances to the homeostasis of the entire organism. Increasing technical possibilities within the field of molecular biology have made possible the search for a connection between organism dysfunction and gene expression. Noting irregularities in the functioning of particular genes gives the possibility to provide not only effective treatment, but equally its control. However, the defining of so-called marker genes is a massive undertaking and in the case of many diseases these are still unknown. In a situation where a given illness is accompanied by stress, or is the cause of its manifestation, it seems to be imperative to distinguish those gene expressions connected with the cell stress response. Cell response to stress is the result of several hundred stress genes [1]. These include genes encoding HSPs or interleukins. Despite many of the genes being described as stress genes, three signalling pathways regulating their expression are currently known [2]. The most important of these is dependent on the protein nuclear factor (NF-kB), which stimulates genes encoding early and late inflammatory response interleukins (IL1, IL6, IL8), and interferes with the path-dependent heat shock

Address for correspondence: Jolanta Góral-Półrola, The Old Polish University, Kielce, Poland

E-mail: jgp@stsw.edu.pl

Received: 30 January 2017; accepted: 14 April; first published on June 2017 factor protein 1 (HSF1) and p53 protein. The consecutive release of pro-inflammatory cytokines in turn stimulates the production of antagonist cytokines, such as IL10. Therefore, any heat stress/shock response (HSR) is dependent on the activity of HSF-1, which mainly affects the expression of genes encoding HSP. According to Polla and Cossarizza, HSP overexpression in human leukocytes is associated with the prevention of the action of pro-inflammatory cytokines [3].

However, research into the connection between psychiatric disturbances and the gene expression associated with stress has been limited. Significantly greater has been the work undertaken on the testing of SNP mutation points and their link to predispositions for certain diseases. In this respect, the research work of Sinclair et al. [4] and Pae et al. $[5,6]$ into SNP testing in the area of HSPA1A and their connection with psychoses, or schizophrenia should be noted [5]. Mehta et al. have noted a link between the polymorphism FKBP5 and the risk of the appearance of post-injury stress disorder [7].

The research available within the subject literature connected with gene expression is chiefly concerned with disturbances, such as schizophrenia $[8,9,10]$, depression $[11$, $12,13]$, anorexia $[14,15]$ or OCD [16]. The cited authors tested genes connected to the immunological response, chiefly that of interleukins, and suggest that disturbance to the immune system in schizophrenia is connected with a reduction in the cell response and an increase in the humoral. Arion et al. [17] pointed out a connection between the overexpression of the genes HSPA1A and HSPB1 during development and the appearance of schizophrenia. Equally important has 
been research into gene activity during the treatment of patients for the use of medication impacts on the expression of the genes NF-kB and proinflammatory cytokines [18]. Such results may be extremely helpful in an individualizing (personalizing) of patient treatment. As a consequence, it has been decided that the present work will attempt to determine the expression of the transcription factors and target genes connected with the HSF-1 and NF- $k B$ pathway.

Tests on hypoxia-inducible factor 1 (HIF-1), which is the activator in the transcription of vascular endothelial growth factor $(V E G F)$ in psychiatric dysfunctions, are also rarely carried out. This factor activates itself in the cell response to hypoxia. HIF-1 is the omnipresent expression in all cells including peripheral leucocytes. According to Shibata et al., changes in the expression of HIF-1 are connected with mood disturbances [19].

\section{OBJECTIVE}

Taking into consideration the present state of knowledge, the aim of this study is to compare the expression of the transcription factors: HSF-1, NF-kB, Hif1 and HSPA1A, HSPB1 IL6, IL10 and CRP in a patient with PTSD treated at the Reintegration Training Centre of the Polish Neuropsychological Society, when compared to healthy individuals.

\section{CASE STUDY}

The patient and case study was a 57-year-old male, a retired Polish Army lieutenant-colonel, treated at the Reintegration Training Centre of the Polish Neuropsychological Society, and in whom a strong case of PTSD had been diagnosed. Following the attack on the World Trade Center, he saw two tours of duty with a military mission in Lebanon. He worked as an assistant commander of a field hospital for six months, and was exposed to severe traumatic experiences and the helplessness connected with this duty. As an example, he evacuated patients after an explosion during which he witnessed the death and mutilated body of his friend, as well as the deaths of several colleagues. He received a slight wound during a dangerous exchange of fire: a fragment of glass injured his head. He did not lose consciousness and the wound was stitched, leaving a small scar on the scalp. However, there occurred in him symptoms which appear in Mild Traumatic Brain Injury, such as: headaches, dizziness, nausea/vomiting, attention deficit, memory problems, irritability, fatigue, ringing in the ears, and a sensitivity to noise and light. These symptoms, after about a year, almost completely disappeared. However, several years later, the patient's condition started to deteriorate drastically and there appeared disturbances in both his psychic and psychophysical functioning, which were classified as PTSD. Since 2010, he has been retired, although he continues to be treated psychiatrically and neurologically.

The presence of post-traumatic stress disorder in accordance with the DSM 5 criteria (cf. Tab. 1) was ascertained during a comprehensive clinical diagnosis.

Table 1. Criteria (categories) and DSM 5. [Diagnostic criteria 309.81 (F43.10)]

\begin{tabular}{|c|c|c|}
\hline Code & Criteria (categories) and symptoms of PTSD according to DSM-5 & Description of symptoms of PTSD in the patient \\
\hline A & $\begin{array}{l}\text { Exposure to actual or threatened death, serious injury, or sexual violence in one (or } \\
\text { or more) of the following ways: }\end{array}$ & \\
\hline A1 & Directly experiencing the traumatic event(s). & $\begin{array}{l}\text { Exposure to threatened death. In one of the shooting incidents he } \\
\text { was wounded in in the head by a piece of glass from a car window. } \\
\text { Mild TBI appeared. }\end{array}$ \\
\hline A2 & Witnessing, in person, the event(s) as it occurred to others. & $\begin{array}{l}\text { Witnessing the actual death of his close ar friend and the deaths of } \\
\text { several colleagues. }\end{array}$ \\
\hline A3 & $\begin{array}{l}\text { Learning that the traumatic event(s) happened d to a close family member or close friend. } \\
\text { In cases of actual or threatened death of a family member or friend, the event(s) must } \\
\text { have been violent or accidental. }\end{array}$ & $\begin{array}{l}\text { Learning that the traumatic events occurred to resulting in actual } \\
\text { violent death and Also the threatened the death of colleagues. }\end{array}$ \\
\hline A4 & $\begin{array}{l}\text { Experiencing repeated or extreme exposure to aversive details of the traumatic event(s) } \\
\text { (e.g., first responders collecting human remains: police officers repeatedly exposed to the } \\
\text { details of child abuse). }\end{array}$ & $\begin{array}{l}\text { Experiencing extreme exposure to aversive details of the traumatic } \\
\text { event (first responder collecting the human remains of a close } \\
\text { friend). }\end{array}$ \\
\hline B & $\begin{array}{l}\text { Presence of one (or more) of the following intrusion symptoms associated with the } \\
\text { traumatic event(s), beginning after the traumatic event(s) occurred: }\end{array}$ & \\
\hline B1 & Recurrent, involuntary, and intrusive distressing memories of the traumatic event(s). & $\begin{array}{l}\text { Recurrent daily presence of involuntary, and intrusive distressing } \\
\text { memories. }\end{array}$ \\
\hline B2 & $\begin{array}{l}\text { Recurrent distressing dreams in which the content and/or effect of the dream are related } \\
\text { to the traumatic event(s). }\end{array}$ & $\begin{array}{l}\text { Recurrent (almost every night) distressing dreams in which the } \\
\text { content and sometimes the effect of the dream are related to the } \\
\text { traumatic events. }\end{array}$ \\
\hline B3 & $\begin{array}{l}\text { Dissociative reactions (e.g., flashbacks) in which the individual feels or acts as if the } \\
\text { traumatic event(s) were recurring. (Such reactions may occur on a continuum, with the } \\
\text { most extreme expression being a complete loss of awareness of present surroundings. }\end{array}$ & $\begin{array}{l}\text { Flashbacks in which he feels or acts as if the traumatic event(s) } \\
\text { occurs on a continuum, with the most extreme expression being } \\
\text { almost a complete loss of of awareness of his present surroundings. }\end{array}$ \\
\hline B4 & $\begin{array}{l}\text { Intense or prolonged psychological distress at exposure to internal or external cues that } \\
\text { symbolize or resemble an aspect of the traumatic event(s). }\end{array}$ & None \\
\hline B5 & $\begin{array}{l}\text { Marked physiological reactions to internal or external cues that symbolize or resemble an } \\
\text { aspect of the traumatic event(s). }\end{array}$ & None \\
\hline
\end{tabular}

C Persistent avoidance of stimuli associated with the traumatic event(s), beginning

C after the traumatic event(s) occurred, as evidenced by one or both of the following: 
Table 1. Criteria (categories) and DSM 5. [Diagnostic criteria 309.81 (F43.10)] (Continuation)

\begin{tabular}{ll}
\hline Code & Criteria (categories) and symptoms of PTSD according to DSM-5 \\
C1 & $\begin{array}{l}\text { Avoidance of or efforts to avoid distressing memories, thoughts, or feelings about or } \\
\text { closely associated with the traumatic event(s). }\end{array}$ \\
C2 $\quad \begin{array}{l}\text { Avoidance of or efforts to avoid external reminders (people, places, conversations, } \\
\text { activities, objects, situations) that arouse distressing memories, thoughts, or feelings } \\
\text { about or closely associated with the traumatic event(s). }\end{array}$ \\
D $\quad \begin{array}{l}\text { Negative alterations in cognitions and mood associated with the traumatic event(s), } \\
\text { beginning or worsening after the traumatic event(s) occurred, as evidenced by two } \\
\text { (or more) of the following: }\end{array}$ \\
D1 $\begin{array}{l}\text { Inability to remember an important aspect of the traumatic event(s) (typically due } \\
\text { to dissociative amnesia and not to other factors, such as head injury, alcohol, or } \\
\text { drugs). }\end{array}$ \\
D2 $\begin{array}{l}\text { Persistent and exaggerated negative beliefs or expectations about oneself, others, or the } \\
\text { world (e.g., 'I am bad', 'No one can be trusted', 'The world is completely dangerous', 'My } \\
\text { whole nervous system is permanently ruined'). }\end{array}$ \\
\hline
\end{tabular}

D3 Persistent, distorted cognitions about the cause or consequences of the traumatic event(s) that lead the individual to blame himself/herself or others.
Description of symptoms of PTSD in the patient

Avoid distressing memories about the traumatic event(s).

Avoid external reminders (conversations and objects) that arouse distressing memories about the traumatic event(s).

Inability to remember an important aspect of the traumatic event(s) (due to dissociative amnesia).

Persistent and exaggerated negative beliefs or expectations about oneself and the world: often claimed that 'Man can't do anything'; 'Various things happen in life'.

Persistent, distorted cognitions about the consequences of the traumatic event(s) that lead the individual to blame himself or others.

Persistent negative emotional state (anger, and less frequently fear). He does not participate at all in significant activities. Feelings of detachment from others.

Persistent inability to experience happiness, satisfaction, or love for his closest family.

D7 hersistent inability to experience positive

Marked alterations in arousal and reactivity associated with the traumatic event(s),

E beginning or worsening after the traumatic event(s) occurred, as evidenced by two (or more) of the following:

Irritable behaviour and angry outbursts (with little or no provocation) typically expressed as verbal or physical aggression toward people or objects.

Irritable behaviour and angry outbursts (with no provocation) typically expressed as verbal aggression towards people.

E2 Reckless or self-destructive behaviour. None

E3 Hypervigilance. Hypervigilance, mainly during the day.

E4 Exaggerated startle response. None

E5 Problems with concentration. He is not able to concentrate on the topic of conversation or during a long task.

E6 Sleep disturbance (e.g., difficulty with falling asleep, staying asleep, or restless sleep). Sleep disturbance (difficulty falling asleep and restless sleep).

F Duration of the disturbance (Criteria B, C, D, and E) is more than 1 month. Duration of the disturbance (Criteria B, C, D, and E) is more than 1 year.

The disturbance causes clinically significant distress or impairment in social, occupational, or other important areas of functioning.

The disturbance causes clinically significant distress and impairment in social areas of functioning.

The disturbance is not attributable to the physiological effects of medication or alcohol) dreamlike, distant, or distorted).

He feels recurrent experiences of the unreality of surroundings: the world around is experienced as unreal and distant.

Source: Półrola et al. [13], with modification]

On MR images, brain parenchymal atrophy was prominent in the regions of the right medial prefrontal cortex, right hippocampus, and right amygdala. In the right temporal lobe, post-traumatic gliosis was also visible.

Two areas of the brain have been identified as altered in PTSD: the amygdale and hippocampus. Combat veterans of the Vietnam war with PTSD showed a $20 \%$ reduction in the volume of their hippocampus, compared with veterans who had suffered no such symptoms. The hippocampus is associated with the ability to play memories in the correct context of time, and with the ability to recall these memory; during high stress times its activity is suppressed. This suppression in hypothesized to be the cause of the flashbacks that often plague PTSD patients. Amygdala has been shown to be strongly involved in the formation of emotional fearrelated memories; in PTSD it is associated with hyperarousal $[13,19,20,21,22]$. 

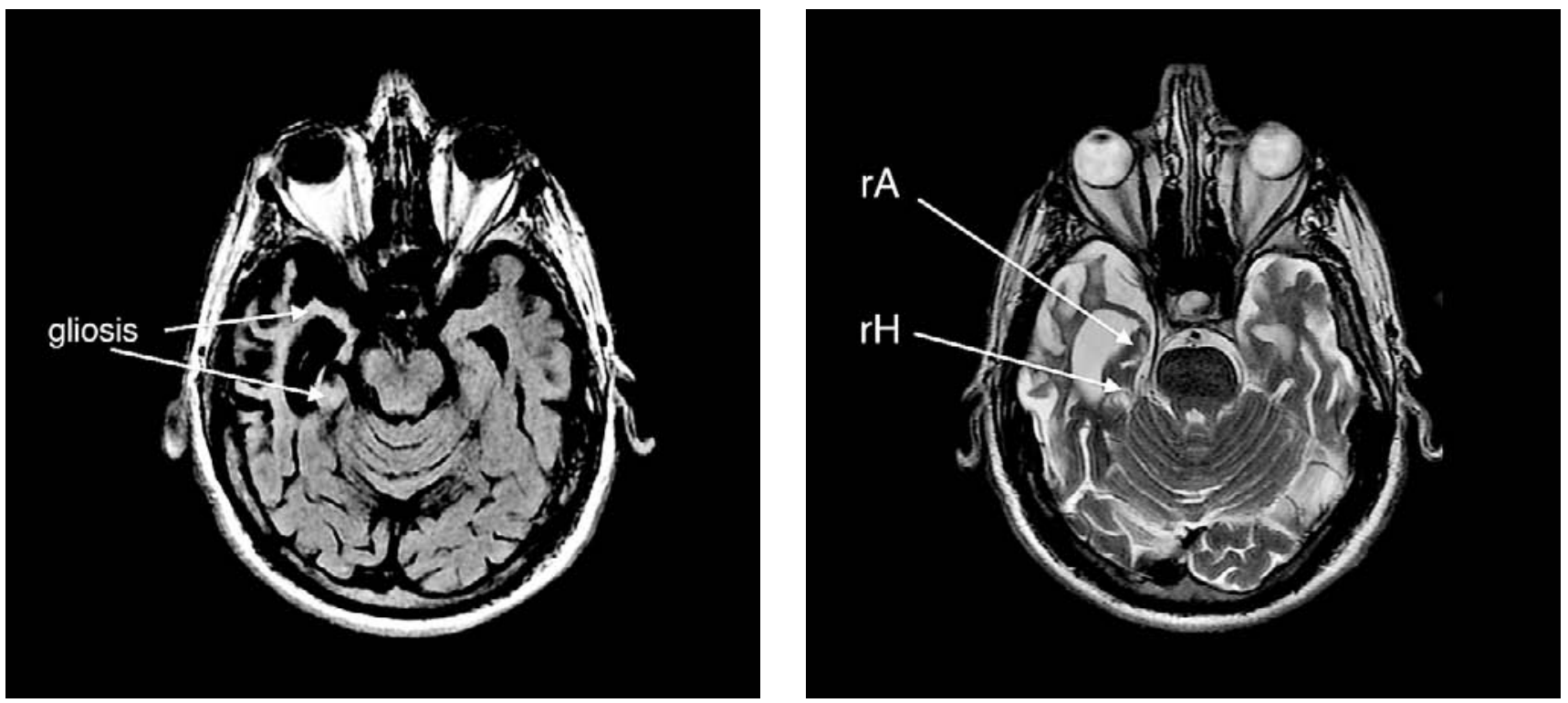

Figure 1. a) Brain MRI, FLAIRT2 sequence, axial plane: hyper-intensity of the brain tissue - signs of gliosis (arrow); b) Brain MRI, frFSET2 sequence, axial plane: predominant atrophy of the right Hippocampus ( $\mathrm{rH}$ arrow) and right Amygdala (rA arrow)
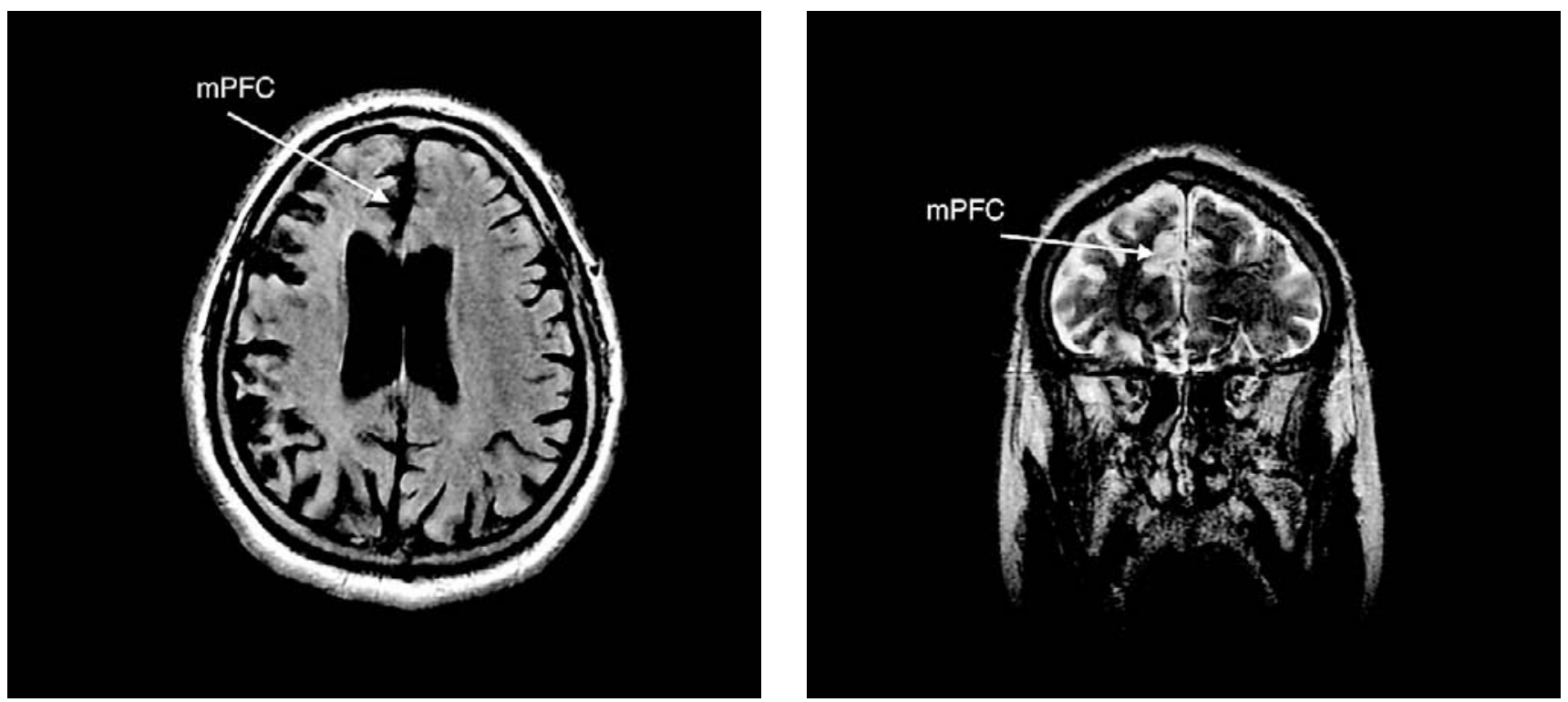

Figure 2. a) Brain MRI, FLAIRT2 sequence: axial plane: predominant atrophy of the right medial prefrontal cortex (mPFC arrow); b) Brain MRI, frFSET2 sequence, coronal plane: predominant atrophy of the right medial prefrontal cortex (mPFC arrow)

\section{MATERIAL AND METHODS}

Participants. The patient A.P. and 20 healthy people took part in our experiment. All procedures and the time of blood collection were the same for the patient and those from the control group.

RNA isolation and reverse transcription. In order to isolate RNA, $2 \mathrm{ml}$ of venous blood were collected from the ulnar vein. The isolation of RNA was performed with reference to the Chomczynski and Sachi [20] method using a TRIZOL reagent (LifeTechnologies, Department Poland). The isolated RNA was purified with DNaza I (Initrogen, LifeTechnologies, Department Poland) in order to rid it of DNA. The purity and concentration of the obtained RNA was determined spectrophotometrically (Eppendorf BioPhotometer Plus, Germany). A reverse transcription was performed from
$2 \mu \mathrm{l}$ RA using the Transcript Me RNA kit (DNA, Gdańsk, Poland). Remnant RNA was purified by RAaza H. After the reverse transcription the $\mathrm{c}-\mathrm{DNA}$ was stored at $-20^{\circ} \mathrm{C}$.

Q-PCR. Real Time PCR was performed in three technical replicates using Light Cycler 480II (Roche, Department Poland). The reaction mixture contained: $5 \mu$ l of Light Cycler Polimerase (Roche, Department Poland), $0.25 \mu \mathrm{l}$ of each, reverse and forward primers, $2 \mu \mathrm{l}$ of cDNA and water to a final volume of $10 \mu \mathrm{l}$. The thermal profile of the PCR was consistent with the manufacturer's instructions. In order to calculate the level of genes expression, the Schmigtten and Livak $\Delta \Delta \mathrm{C}_{\mathrm{t}}(22)$ method was used. S18 was measured as a reference gene. Primers used in the PCR reaction are shown in Table 2.

Proportions between genes encoding: transcription factors, interleukin and heat shock protein are shown in Table 3. 
Table 2. Primers used in the PCR reaction

\begin{tabular}{ll}
\hline Gene & Primers \\
HSPA1A & R: TTCGGAGAGTTCTGGGATTGTA \\
& F: TGGACTGTTCTTCACTCTTGGC \\
HSPB1 & R: GAGGAAACTGGGTGGGTCCA \\
& F: AAGGATGGCGTGGGGAGATCA \\
\hline IL6 & R: GACATCAAGGCGCATGTGAAC \\
\hline \multirow{2}{*}{ IL10 } & F:TCCACGGCCTTGCTCTTGTI \\
\hline \multirow{2}{*}{ CRP } & F: GATTCGGTACATCCTCGACGG \\
\hline HSF-1 & R: TCTTGGTCTTGACCAGCCTCT \\
\hline \multirow{2}{*}{ NF-kB } & R: CAGGAGCTTGGAGTCCATGCA \\
\hline HIF-1 & R:GAGCAGCTCCTTGAGAACATC \\
\hline
\end{tabular}

Statistical Analysis. For the control group $(n=20)$, the mean and SD were calculated. All the calculations and graphical presentations of the results were performed in GraphPad Prism 6.0 (graphpad.com). To improve the visualisation changes in expression, the rest value was set to 1 .

\section{RESULTS}

Figure 3 shows the differences in the expression of the genes tested in relation to the patient and the control group.

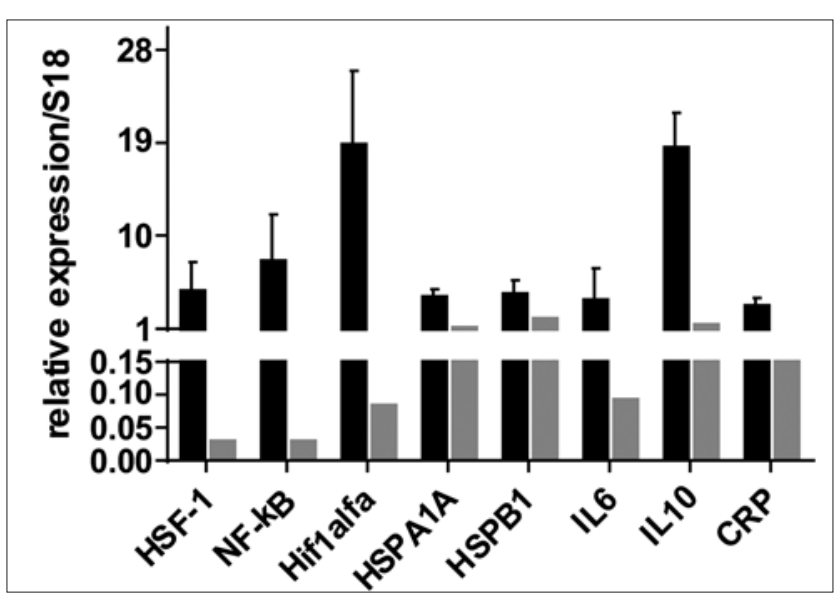

Figure 3. Differences in genes expression in leukocytes between patient (grey bars) and the control group (dark bars). For better visualization, the rest value was set to 1 .

There was noted in the patient an extremely low expression of the genes tested - those associated with cell stress response. The expression of the transcription factors: HSF-1, NF- $k B$, Hif1 and $I L-6$ m-RNA was noticeably reduced and represented, respectively: $0.028 ; 0.271 ; 0.081 ; 0.09$. As a consequence of the normalisation of results within the control group, the lowest level of expression for the tested genes was 1. Expression of the genes HSPA1A, HSPB1 and IL10 $(1.08 ; 1.98 ; 1.29)$ was equally low, i.e., on the level of the lowest result obtained in the control group. Table 2 presents the proportions among the gene expression of HSPA1A/HSPB1, IL6/IL10 and HSF-1/ NF-kB/HIF1 alfa. The proportions were calculated quantities Qt (number copy of transcript).
Table 3. Proportions between genes encoding: transcription factors, interleukin and heat shock protein

\begin{tabular}{lcc}
\hline Proportions & Control group & Patient \\
\hline HSPA1A/HSPB1 & $7 / 1$ & $1 / 4$ \\
\hline HSF/NF/HIF & $0,5 / 0.01 / 1$ & $1 / 1 / 1$ \\
\hline IL6/IL10 & $0,95 / 1$ & $1,72 / 1$ \\
\hline
\end{tabular}

There are differences in the reciprocal ratio of all the tested genes. In the control group, the expression of HSPA1A was 7-fold greater than HSPB1, whereas in the patient, HSPB1 was 4 -fold higher than HSPA1A. These differences also relate to IL6/IL10, wherein the patient had a higher level of pro-inflammatory cytokine, while in the control group this proportion was close to 1 . In comparison with the control group, in this patient the proportions in transcriptional factors were also different, higher in $N F-k B$ and $H S F-1$ activity.

\section{DISCUSSION}

There was noted in the PTSD patient a level of HSPA1A and HSPB1 m-RNA that was lower than the control-group average, yet still within the scope for internal-group changes. There was also noted a significantly low expression for the transcription factors: HSF-1,NF-kB and Hif-1 alfa, as well as IL6 (tens or hundredths of the values of the lowest result obtained in the control group). Given the significant differences in expression of the transcription factors tested and of the interleukin 6 gene between the patient and the control group, it seems likely that the lowered expression of these genes might be linked to PTSD.

There is available within the subject literature research suggesting disturbances to the immune system in certain diseases, such as schizophrenia $[8,9,10]$, depression $[11$, $12,13]$, anorexia $[14,15]$ or OCD [16]. Freudenreich et al. [9] suggest that disturbances to the immune system in schizophrenia are linked to a reduced level in cell response, and an increase in the humoral response. In research into gene expression in those suffering from schizophrenia $(n=15)$ the authors have stated the presence of a reduced level of expression IL1, as well as a correct level of IL10 in comparison to healthy individuals. In own research into the presented PTSD patient, there was noted an extremely low expression of IL 6 as well as a lowered (falling within the scope of changes noted in the control group) level of IL10, which may also indicate cell disturbance in the immune response [20,21, 22]. In turn, Bocchio Chiavetto et al. [18] in tests on IL6 and IL10 in women suffering from anorexia, have claimed a noted increase in the expression of IL6. The data cited shows that amongst genes connected with an immune response there is the possibility of finding a marker gene. However, to draw such far-reaching conclusions would be possible only through the conducting of research on numerically larger groups representing various illnesses and diseases. Research to-date into gene expression in patients with diagnosed PTSD has been very limited. Guardado et al. [21] have claimed disturbances in the regulation of genes associated with an immune response, as well as the NF-kB regulating pathway. This is all in accordance with the results obtained in the presented patient. Mehta et al. [7] mention the effect of SNP in FKBP5 on a tendency for PTSD development. In turn, Pace 
et al. [22], in researching the NF-kB dependent pathway, have claimed an increase in its activity in women with PTSD. In the case of the presented patient, no such dependence was found. Certainly of significance for the interpretation of the results was the use in these patients of pharmacological and neuropsychological treatment. As Horowitz et al. [12] note that following the application of the medicine Venlafaxine or EPA, the level of expression of IL6 and NF- $k B$ radically decreases.

In recent years, research has been started into the link between the expression in the transcription factor Hif-1 alfa and pathophysicological mood [13]. The cited authors have claimed an increase in the level of HIF-1 m-RNA in depression and in bipolar psychosis. The changed expression in HIF-1 also applied to the mRNA of genes regulated through HIflin peripheral blood cells, and in the view of the authors this was connected with the occurrence of mood disturbances (particularly with MDD). In own research, there was also noted the expression of HIF-1 alfa, as well as confirmation of a reduction in its level.

\section{CONCLUSIONS}

It is possible, that the lower level of transcriptional factors: $H S F-1, N F-k B$ and Hif- 1 as well as IL6 m-RNA may be associated with the effect of the PTSD patient's treatment.

\section{REFERENCES}

1. Imadome K, Iwakawa M, Nojiri K, Tamaki T, et al. Upregulation of stress-response genes with cell cycle arrest induced by carbon ion irradiation in multiple murine tumors models, Cancer Biology \& Therapy, 2008; 7: 2, 208-217. http://dx.doi.org/10.4161/cbt.7.2.5255

2. Perkins N.D., Integrating cell-signalling pathways with NF-kappaB and IKK function. Nat. Rev. Mol. Cell Biol. 2007; 8:49-62. https://dx.doi. org/10.1038/nrm 2083

3. Polla BS, Cossarizza A. Stress protein in inflammation. EXS. 1996; 77: 375-391. http://link.springer.com/chapter/10.1007/978-3-03489088-5_25\#page-1

4. Sinclair D, Fillman SG, Webster MJ, Weickert CS. Dysregulation of glucocorticoid receptor co-factors FKBP5, BAG1 and PTGES3 in prefrontal cortex in psychotic illness. Sci Rep. 2013; 3: 3539. https:// dx.doi.org/10.1038/srep03539

5. Kim JJ, Mandelli L, Lim S, Lim HK, et al. Association analysis of heat shock protein 70 gene polymorphisms in schizophrenia. Eur Arch Psychiatry Clin Neurosci. 2008; 258(4): 239-44. https://dx.doi. org/10.1007/s00406-007-0791-6

6. Pae CU, Mandelli L, Serretti A, Patkar AA, et al. Heat-shock protein-70 genes and response to antidepressants in major depression. Progress in Neuro-psychopharmacology \& Biological Psychiatry 2007; 31(5): 1006-11. http://dx.doi.org/10.1016/j.pnpbp.2007.02.011

7. Mehta D, Gonik M, Klengel T, Rex-Haffner M, et al. Using polymorphisms in FKBP5 to define biologically distinct subtypes of posttraumatic stress disorder: evidence from endocrine and gene expression studies. Arch Gen Psychiatry. 2011; 68(9): 901-10. https:// dx.doi.org/10.1001/archgenpsychiatry.2011.50
8. Chase KA, Rosen C, Gin H, Bjorkquist O, Feiner B, Marvin R, Conrin S, Sharma RP. Metabolic and inflammatory genes in schizophrenia. Psychiatry Res. 2015 Jan 30; 225(1-2): 208-11. https://dx.doi. org/10.1016/j.jpsychires.2015.04.005

9. Freudenreich O, Brockman MA, Henderson DC, Evins AE, et al. Analysis of peripheral immune activation in schizophrenia using quantitative reverse-transcription polymerase chain reaction (RT-PCR). Psychiatry Res. 30; 176(2-3): 99-102. https://dx.doi.org/10.1016\%2Fj. psychres.2008.11.007

10. Trystuła M, Zielińska J, Półrola P, Góral-Półrola J, Kropotov JD, Pąchalska M. Neuromarkers of anxiety in a patient with suspected schizophrenia and TIA: the effect of individually-tailored neurofeedback. Acta Neuropsychologica. 2015; 13(4): 395-403.

11. Mirski A, Pąchalska M, Moskała M, Orski M, Orska M, Miąskiewicz M, Zapała J, Kropotov JD. Neuromarkers of anxiety and depression in a patient after neuro-ophthalmic surgery of the meningioma - effect of individually-tailored tDCS and neurofeedback. Ann Agric Environ Med. 2015; 22(4): 730-735. https://dx.doi.org/10.5604/12321966.1185783

12. Horowitz MA, Wertz J, Zhu D, Cattaneo A, et al. Antidepressant compounds can be both pro- and anti-inflammatory in human hippocampal cells. Int. Neuropsychopharmacol. 31; 18(3). Int J Neuropsychopharmacol. 2014; 31; 18(3). https://dx.doi.org/10.1093/ijnp/ pyu076

13. Półrola P, Kaczmarek BLJ, Góral-Półrola J, Kropotov JD, HermanSucharska I, Pąchalska M. Event-related potential studies of combined mild traumatic brain injury/post-traumatic stress disorder in a retired Polish Army lieutenant colonel. Acta Neuropsychologica 2016; 14(1): 69-91.

14. Kropotov JD. Quantitative EEG, Event-Related Potentials and Neurotherapy. Academic Press, Elsevier 2009. ISBN: 978-0-12-374512-5

15. Kahl KG, Kruse N, Rieckmann P, Schmidt MH. Cytokine mRNA expression patterns in the disease course of female adolescents with anorexia nervosa. Psychoneuroendocrinology. 2004 Jan; 29(1): 13-20. https://www.ncbi.nlm.nih.gov/pubmed/14575726

16. Zielińska J, Goral-Połrola J, Połrola P, Łuckoś M, Kropotov JD, Pąchalska M. Hyper-frontality in an OCD patient - evidence from event-related potentials in a cued GO/NOGO task. Ann Agric Environ Med. 2016; 23(2): 276-279. https://dx.doi.org/10.5604/12321966.1203890

17. Arion D, Unger T, Lewis DA, Levitt P, Mirnics K. Molecular evidence for increased expression of genes related to immune and chaperone function in the prefrontal cortex in schizophrenia. Biol Psychiatry. 2007 Oct 1; 62(7): 711-21. https://dx.doi.org/10.1016/j.biopsych.2006.12.021

18. Bocchio Chiavetto L, Boin F, Zanardini R, Popoli M, Michelato A, Bignotti S, Tura GB, Gennarelli M. Association between promoter polymorphic haplotypes of interleukin-10 gene and schizophrenia. Biol Psychiatry. 2002 Mar 15; 51(6): 480-4. http://dx.doi.org/10.1016/ S0006-3223(01)01324-5

19. Shibata T, Yamagata H, Uchida S, Otsuki K, Hobara T, Higuchi F, Abe $\mathrm{N}$, Watanabe Y. The alteration of hypoxia inducible factor-1 (HIF-1) and its target genes in mood disorder patients. Prog Neuropsychopharmacol Biol Psychiatry. 2013; 3; 43: 222-9. https://dx.doi.org/10.1016/j.pnpbp. 2013.01.003

20. Chomczynski P, Sacchi N. Single-step method of RNA isolation by acid guanidinium thiocyanate-phenol-chloroform extraction. Anal. Biochem. 162(1): 156-9. http://dx.doi.org/10.1016/0003-2697(87)90021-2

21. Guardado P, Olivera A, Rusch HL, Roy M, Martin C, Lejbman N, Lee H, Gill JM. Altered gene expression of the innate immune, neuroendocrine, and nuclear factor-kappa $\mathrm{B}(\mathrm{NF}-\kappa \mathrm{B})$ systems is associated with posttraumatic stress disorder in military personnel. J Anxiety Disord. 2015; 38: 9-20. https://www.ncbi.nlm.nih.gov/pubmed/26751122

22. Pace TW, Wingenfeld K, Schmidt I, Meinlschmidt G, Hellhammer DH, Heim CM. Increased peripheral NF- $\kappa B$ pathway activity in women with childhood abuse-related posttraumatic stress disorder. Brain Behav Immun. 2012 Jan; 26(1): 13-7. https://www.ncbi.nlm.nih.gov/ pubmed/21801830 